\title{
THE MUSEUM EXHIBITION AS THE DISCOVERY OF THE REGIONAL SPECIFITY
}

\author{
Evgeny Kiselev \\ Mr, Ural State University of Economics, kiselev.59@mail.ru
}

\begin{abstract}
The article is devoted to an actual problem of modern museum expositions creation in regional museums. Tourism, as a new cultural phenomenon in business, reflects changes in modern Russian museums. In Russia, modern expositions of regional museums should correspond to current tourist interest in regional history and culture. Hence, creation of expositions should reveal regional specificities. It is necessary to determine perspective directions in which changes will occur. Museums play a key role in the formation of a touristic region; through museums we can see how this city has changed, what had happened in the past and where the accents of regional specifics are now. We examined and analyzed the history of museum expositions that have been taking place from late 19th century until present days in Yekaterinburg, Russia. At different periods of history, museums have been constantly addressing the regional historical and cultural component, emphasizing various aspects, surrounding everyday life in the region at different historical periods. Political life and regional specificity such as industry, production, applied arts, affected museum exhibitions to varying degrees. Nowadays, the emergence of new expositions, new museums, and new facilities increases both the flow of tourists and the interest of local people to history of their native land. Moreover, It promotes the need to train qualified guides. The museum of regional history provides a lot of opportunities to develop modern culture and form new branches of economy in the region, such as tourism.
\end{abstract}

Keywords: museum, tourism, history, culture, exhibition

\section{INTRODUCTION}

The article is devoted to an actual problem of modern museum expositions creation in regional museums. Tourism, as a new cultural phenomenon in business, reflects changes in modern Russian museums. In Russia, modern expositions of regional museums should correspond to current tourist interest in regional history and culture. Hence, creation of expositions should reveal regional specificities. It is necessary to determine perspective directions in which changes will occur (Ruge A., ed., 2008).

Museums play a key role in the formation of a touristic region; through museums we can see how this city has changed, what had happened in the past and where the accents of regional specifics are now.

We examined and analyzed the history of museum expositions that have been taking place from late 19th century until present days in Yekaterinburg, Russia. 


\section{ANALYSIS OF MUSEUMS EXPOSITIONS IN YEKATERINBURG/SVERDLOVSK}

The peculiarity of the Urals as a region is directly related to its conquest. The conquest of eastern part of Russia began to 400 years ago. Initially, that was peasant colonization, based on a thin chain of small fortified cities, established as administrative centers.

A special position of the Urals began to stand out with the formation of the Russian Empire in the early 18th century. This was the time when industry was created on the basis of open minerals deposits, primarily iron and copper ores.

The creation and development of metallurgical plants made this region unique in Russia and affected all spheres of life in the Urals. The city of Yekaterinburg originated in 1723 as a metallurgical plant which became the main administrative center for all factories of the region.

Creation of the first collections reflected the specifics of the region. Each large metallurgical plant made a collection of minerals. Samples of minerals were must-have gifts to travelers visiting this region. One of the most famous travelers, who visited city at this time was German scientist Alexander von Humboldt.

The purpose of museums in the 19th century was to compensate the low level of people's education in the country, especially in the region. There were no universities in the Urals, so this function of museums was extremely important.

At the end of the 19th century, Yekaterinburg was a small town in the Russian Empire, located in the east of the Ural Mountains. The first museum, established in Yekaterinburg in 1888, was museum of natural history (Korepanova S., 2007). Its creators and founders were public figures, engineers, members of the Ural Society of Natural Science Lovers. In addition to traditional academic collections, such as herbariums, zoological collections, archaeological collections, samples of plant products were collected.

Not just gems and minerals were collected. There were also raw materials, which were necessary for the work of metallurgical plants and lapidary factories. Models of gold washing and metals mining machines were created and stored in the museum. With the appearance of photography, pictures of different mines, factories, quarries, which were a visual feature of the Urals landscape, distinguishing it from other regions were gathered.

Exhibits were provided free of charge by numerous Ural plants. These were collections of ores, metals and all kinds of factory products. Twenty models of machines, furnaces and other equipment should be specially noted. This gives us an idea of the state of factory technology of that time (Zorina L.,1996).

After the Russian Revolution, Yekaterinburg was renamed Sverdlovsk. This name belongs to one of the Communist party leaders, Yakov Sverdlov. The Sverdlov Museum was created in the city at the same time. Since the 1920s Sverdlovsk has become a new giant industrial center.

The Museum of the Ural Society of Natural Science Lovers was nationalized, became governmental. In 1937, the Geological Museum was established for the International Mineralogical Congress. Delegations of the International Congress made enthusiastic responses about rich collection and numerous samples of minerals of the region. Also, in the 1930s the Art Museum with an exhibition of paintings by Russian artists was established, the Anti-religious museum and the Ural Museum of the Revolution were open.

City's museums were given a new role. They were obliged to talk about the history of the country in accordance with the prevailing political ideology. The museums were given the task to show the history of the working class as a true history of the city and the region (Bagreev E., 1958). Also, museums were supposed to show the leading role of the Communist Party in creation of a new Soviet city. The government invited artists from Moscow and St Petersburg (Leningrad) who had to display the socialist transformations at the factories of the region. The artists created industrial landscapes and portraits of workers, and then paintings remained in museum collections. At this time, museums did not collect objects connected with the history of religion, objects from the life of the exploiting classes, the bourgeoisie and aristocracy. Despite the fact that the ideological function of museums is evident, museums were able to collect and preserve collections that were considered to be destroyed (for instance, icons).

Exhibitions of modern "achievements", economic and political, were created, which demonstrated both samples of products of new plants, photographs of modern productions, new buildings, political posters, and paintings by artists who were supposed to glorify free labor.

After the era of Stalinism, in the 1950s, interest in history of the Ural region started growing. The expositions of museums started to tell about the region special role in the history of the country, its significance in economy and culture. Museum collections were no longer devoted only to the process of industrialization, an 
exhibition of regional applied arts (e.g. products from gems) was created in the Art Museum. It had the obvious meaning that Yekaterinburg and the Ural region has to be associated not only with industry. For instance, cast-iron pavilion of Kasli Metallurgical Plant was saved and reconstructed, an exhibit of the World Exhibition in Paris in 1900, which won Grand Prix. Nowadays, the Kasli Pavilion is the main exhibit of the Museum of Fine Arts in Yekaterinburg; a special room was created for its exposure.

It should be emphasized that new expositions and expanding collections were given to Christian churches closed in the first years of Soviet Russia. At the same time collections of Orthodox icons were started.

In the 1960s, a movement aimed at creation of regional museums spreads across the USSR. Employees of Sverdlovsk museums conduct expeditions, collect exhibits, relevant to various aspects of the region history.

Until the 1960s, there was a big factory in the city center, which was the heart of the city in XVIII, and which made tanks in the years of World War II. In the 60s the government decided to remove factory from the city center. Historical square was created instead of the factory. Giant samples of the Ural minerals were placed in historical square, trees were planted, representing the flora of the region. For the first time in the region an open-air exposition was made of factory tools and mechanisms of the 19th and early 20th centuries. This place had become a favorite vacation spot for the locals. Nowadays, it is necessary to show this place to tourists. It was the first attempt to create museum and public area at the same time.

In the 80 s the museum crisis started. There was a need to change expositions, which had not been updated for a long time. The main expositions of the Local History museum were closed. The building was close for repairs, and was returned to the church in the 90s. In general, the growing interest of citizens in history was accompanied by dissatisfaction with the museum, as well as the way how history was presented, how expositions were created, how the museum worked with visitors. Political museums and expositions about the revolution had completely lost their attractiveness. That year a modern museum was created. Museums became a special place where collections were investigated and systematized. Moreover, museums are increasingly becoming focused on working with audience; they are searching for new forms of interaction.

In the 90s, after the fall of the USSR, the interest in the field of history and culture had grown again, although the emphasis has changed. There was not enough space for exposition; the museums had to give their buildings to church. However, not only the lack of funding was blocking the way for the development of museums in the city. The old concepts of history and its display did not fit in the new time. They interpreted history and culture from class positions. Hence, the museums began to change. The city regained its previous name Yekaterinburg. From a closed industrial center that carried out planned decisions of the state, it became an open large business and tourist center. Undoubtedly, the city needed a regional museum as a modern tourist facility, in which both tourists and citizens could find something unique and specific. This museum should be a leisure and tourist resource at the same time.

In the 1990s, the old museums changed and new ones arose. The Museum of Yekaterinburg History appeared instead of the Sverdlov Museum. Also the museum of the history of jewelry and stone-cutting business of the Urals was established, the Museum of Youth with an avant-garde exhibition was opened occupying a small mansion in the center of the city, which replaced the Komsomol Museum. The museum began to work with visitors in a new way, it offers unusual forms of interaction. In addition, the museum acquired the role of contemporary art gallery, where young artists were actively exhibited. The first public performances are connected with the Museum of Youth. Regional and municipal authorities have shown interest in making regional culture expositions, created by modern art means.

Nowadays, the city's museum area is expanding. New museums appear in the city, such as the Museum of the First President of Russia - Boris Yeltsin (his politic career started in Yekaterinburg), non-governmental museums (e.g. Nevyansk Icon Museum). Different festivals of contemporary art in the region choose the topic of industrialization (e.g. Ural Industrial Biennale of Contemporary Art) not only as the part of history, but also as an important modern cultural component. New museum centers are becoming centers of attraction not only for locals, but also for Russian and foreign tourists (Kiseleva N., Kiseleva M, 2017) .

\section{CONCLUSION}

Thus, at different periods of history museums have been constantly addressing the regional historical and cultural component. Demonstration of regional history in museums provides a lot of opportunities to develop modern culture and form new branches of economy in the region, such as tourism.

The emergence of new expositions, new museums, new facilities such as the Museum of the First President of Russia (Yeltsin Center), increases the flow of tourists, the interest of locals to the history of the place where they live and promotes the need to train qualified guides. (Gudova M., Kiseleva N., Kiselev E., 2017) 


\section{REFERENCE LIST}

Bagreev E., ed. (1958) Ocherki istorii Sverdlovska.

Gudova M., Kiseleva N., Kiselev E. (2017) The projects method in the culture of region discipline in the tourist education (http://ijaedu.ocerintjournals.org/issue/28950)

Kiseleva N., Kiseleva M. (2017) Novyye modnye gorodskiye dzheksursii. Rossiya mezhdu modernizatsiyey i arkhaizatsiyey: 1917-2017 gg. : materialy XX Mezhdunarodnoy nauchno-prakticheskoy konferentsii Gumanitarnogo universiteta, 11-12 April, 2017. T.1.

Korepanova S. (2007) Promyshlennye vystavki Rossii XIX veka: k 120-letiyu Sibirsko-Ural'skoy nauchnopromyshlennoy vystavki $1887 \mathrm{~g}$.

Ruge A., ed. (2008) Museum Professions - A European Frame of Reference

Zorina L. (1996) Istoriya Ural'skogo obshchestva lyubiteley yestestvoznaniya 1870-1929. Uchenyye zapiski Sverdlovskogo oblastnogo krayevedcheskogo muzeya. 1996. Vol.1 